\title{
EFFECTS OF TECHNICAL FACTORS TOWARDS ACHIEVING THE THERMOPHILIC TEMPERATURE STAGE IN COMPOSTING PROCESS AND THE BENEFITS OF CLOSED RECTOR SYSTEM COMPARED TO CONVENTIONAL METHOD - A MINI REVIEW
}

\author{
ALKARIMIAH, R. ${ }^{1 *}-$ SUJA', F. $^{2}$ \\ ${ }^{1}$ School of Civil Engineering, Universiti Sains Malaysia, 14300 Pulau Pinang, Malaysia \\ ${ }^{2}$ Faculty of Engineering and Built Environment, Universiti Kebangsaan Malaysia, 43600 Bangi, \\ Selangor, Malaysia \\ (phone: +60-38-911-8364/8911/8354, fax: +60-38-911-8355) \\ *Corresponding author \\ e-mail: cerosnani@usm.my; phone: +60-45-996-264; fax: +60-45-996-906
}

(Received $9^{\text {th }}$ Apr 2019; accepted $19^{\text {th }}$ Jun 2019)

\begin{abstract}
Composting is the process of organic biological decomposition in aerobic and controlled conditions. Many factors can affect the composting process, and almost all are related. Some factors that majorly affect the composting process also influence the stage or direction of the process. This paper focuses on the technical factors that affect the composting process' achievement of the thermophilic phase, particularly in a closed reactor system. At the same time, this paper will be discussed about the benefits and comparison between close reactor system and the conventional pile method. The technical factors that are discussed in-depth in this mini review paper are the rotation or turning frequency, aeration rates, and the initial moisture of the compost mixture for closed reactor composting system. All three factors significantly cause increased thermophilic temperature in the closed reactor. Basically, there are 3 important phases in the composting process, which are the mesophilic phase, thermophilic phase, and maturation phase. In the composting process, it is crucial that the thermophilic temperature is reached. By increasing the thermophilic temperature, the number of thermophilic microorganisms also increases, causing the rapid degradation of bio-waste
\end{abstract}

Keywords: aeration rates, initial moisture, rotation/turning frequency, thermophilic temperature

\section{Introduction}

The problem of residual waste streams from the industry has worsened. Before industrialization, the production and decomposition of organic matter were essentially balanced. Composting, in general, is not only important in preventing the accumulation of organic waste from harming the environment, but also to recycle nutrients and organic matter. A proper composting process effectively destroys pathogens and weed seeds because in the process a high temperature $\left(55-65^{\circ} \mathrm{C}\right)$ is achieved through the metabolic heat generated by microorganisms in the thermophilic phase (Petric and Selambasic, 2008).

Among the benefits of composting is that plant nutrients are conserved, and harmful substances are transformed into non-hazardous substances; thus, producing reusable products (Liu, 2000). Composting materials from organic waste can also improve the structure of the water-holding capacity of the soil (Mohammad et al., 2012). Furthermore, the benefit of composting nowadays is not limited to landfills, but also for controlling and preventing environmental pollution. Composting materials are now used 
to control soil erosion on highways. It also works for cleaning runoff in running water and for recovering soil contaminated with heavy metals or toxic organic compounds (Bhattarai et al., 2011).

Compost stability and maturity have an important impact on the application of the compost's final product in land use. The use of immature and unstable compost products because of an incomplete biodegradation process can negatively affect germination and reduce plant fertility, which causes competing absorption of oxygen and toxicity (Zhang et al., 2017). The application of unstable and immature compost would fix nitrogen in the soil and limit plant growth because it competes for oxygen in the rhizosphere and discharges toxic substances (Bernal et al., 2009). According to many researchers, matured compost products from composting at thermophilic temperature are eco-friendlier (Bernal et al., 1998; Yang et al., 2013; He et al., 2014).

Most of the composting system used is conventional technology which is by adapting the pile method. The pile method, if not properly maintained, will cause many problems, for example the presence of wild animals and require more sophisticated operation controls and require large space and a need long time to produce the product. Hence, composting using mechanical methods such as closed reactors is easier and able to overcome problems resulting from composting rather than using pile methods. The goal of the reactor's mechanical design is to accelerate the composting process through optimum maintenance for active microbes during composting and to minimize adverse effects on the environment (Bertoldi et al., 1983). Mechanical systems can process large amounts of waste without taking up much space, and they offer good control of the environmental conditions such as temperature, moisture content, and airflow rate (Alkoaik et al., 2018). The mechanical system is usually closed, however there are researchers using an open reactor system. However, mechanical closed reactor systems have good control which makes it more suitable for composting in large quantities (Bhamidimarri and Pandey, 1996; Haug, 1993). In general, pile methods and mechanical methods can be distinguished on several criteria such as capital costs, operational costs, land requirements, operating controls and so on (Habsah, 2008). Table 1 describes the comparison of both pile and closed mechanical methods. From the table below, pile composting method are more exposed to the influenced of weather, which will at the same time influence the temperature rise of the pile. Adapting pile/windrow system also lead to leachate contamination posing a risk of groundwater contamination GHG emissions, space limitation and emission of greenhouse gases (Rich and Bharti, 2015). Zhu-Barker et al. (2017) mentioned that windrow composting system is a source of greenhouse gases (GHG) that contribute to climate change. In their study, found that pile compost during the rainy season with cooler temperature resulted in oxygen depleted environment that generated the highest $\mathrm{CH}_{4}$ and lowest $\mathrm{N}_{2} \mathrm{O}$ emissions. Chen et al. (2015) also studied the $\mathrm{N}_{2} \mathrm{O}$ emission during the composting of dairy manure by windrow system. They found out pile turning altered the distributions of $\mathrm{NO}_{3}{ }^{-}$and $\mathrm{NO}_{2}{ }^{-}$in the compost materials and dramatically influenced surface windrow $\mathrm{N}_{2} \mathrm{O}$ emissions.

The process of composting is a biological one and thus involves various microorganisms. These organisms will break down organic matter and organic compounds. The identification of microorganisms capable of decomposing certain compounds is very useful in the composting process. Organic waste is decomposed during the process of fertilization by replacing microbial communities with complex and critical substrata such as cellulose, lignin, and hemicellulose (Hiroaki et al., 2006). 
Composting-related organisms can be classified into two classes, namely mesophyll and thermophile. Classification of microorganisms according to the temperature in which they live and grow. Temperature plays an important role in the composting process, as it affects microbial activity. Hoseini and Abdul Aziz (2013) also indicate temperature as a key factor for determining the progress of the composting process; a higher temperature (thermophilic conditions) results in a higher decomposition of organic matter $(\mathrm{OM})$.

Several researchers concluded that using a single-maturity index was insufficient to indicate compost maturity and stability (Rashad et al., 2010). However, many other researchers used the thermophilic stage of the composting process as a key factor for specifying the success of the entire process (Sarkar et al., 2016; Han et al., 2018; Koyama et al., 2018; Gou et al., 2017; Awasthi et al., 2017; Hoseini and Abdul Aziz 2013; Li et al., 2014). Therefore, this paper discusses and reviews the factors that significantly impact thermophilic temperature achievement, especially in a closed reactor, either lab-scale or pilot-scale. The factors that are discussed include rotation/turning frequency, aeration rate, and initial moisture of the compost mixture.

Table 1. Comparison between pile composting and mechanical methods. (Source: Habsah, 2008)

\begin{tabular}{|c|c|c|}
\hline Criteria & Pile method & Closed mechanical reactor \\
\hline Capital Cost & Low & High \\
\hline Operational cost & Low & Low \\
\hline Land requirement & High & $\begin{array}{l}\text { Low. Can increase if the } \\
\text { resulting compost needs to be } \\
\text { matured in a pile method }\end{array}$ \\
\hline Ventilation control & Limited. Unless forced aeration is done & No limit \\
\hline Operation control & $\begin{array}{l}\text { Turning frequency, parameter correction } \\
\text { (moisture, } \mathrm{pH}, \mathrm{C} / \mathrm{N})\end{array}$ & $\begin{array}{l}\text { Airflow rate, dynamic of turning } \\
\text { process, parameter correction } \\
\text { (moisture, pH, C/N), recycling }\end{array}$ \\
\hline $\begin{array}{l}\text { Sensitivity to weather } \\
\text { changes }\end{array}$ & $\begin{array}{c}\text { Sensitive. Need to be covered with plastic } \\
\text { canvas }\end{array}$ & \begin{tabular}{|c|} 
Can operate at any weather. But \\
it depends on the material
\end{tabular} \\
\hline Odor control & Depending on the organic material used & Good \\
\hline Problem in operation & Easily influenced by uncertain weather & $\begin{array}{l}\text { Potential for short circuit, } \\
\text { complex mechanical process }\end{array}$ \\
\hline
\end{tabular}

\section{Thermophilic temperature}

Temperature is a substantial measurement that could affect the composting process and the microbial activity during composting (Sun et al., 2017; Morales et al., 2016; Zhao et al., 2016). At the same time, it is also a function of the process. During the aerobic composting process, there are three phases affecting the microbial population. The first is the mesophilic phase (ambient temperature up to $45^{\circ} \mathrm{C}$ ), followed by the thermophilic phase $\left(45^{\circ} \mathrm{C}->60^{\circ} \mathrm{C}\right)$ and finally returning to the mesophilic phase $\left(45^{\circ} \mathrm{C}\right.$ to the surrounding temperature) as shown in Figure 1. Temperature does not only affect the metabolic process of microorganisms, but these parameters are also seen to affect the density and composition of microbes in the compost mass (Liang et al., 2003). Because temperature impacts microbiological processes, important responses and other elements of the composting process are also affected by temperature changes (Epstein, 1997). It was reported that a composting temperature set to $55^{\circ} \mathrm{C}$, enabled the 
killing off of pathogens and sanitization of compost material (Gea et al., 2005). Stentiford (1996) also found that maximum temperatures of $55-65^{\circ} \mathrm{C}$ were necessary to destroy pathogens, but temperatures within the range of $45-55^{\circ} \mathrm{C}$ must be maintained for maximum biodegradation in the composting process. Additionally, temperatures below $20^{\circ} \mathrm{C}$ and more than $60^{\circ} \mathrm{C}$ have been shown to reduce microbial activity (Liang et al., 2006). However, Wong et al. (2001) agreed that a $60^{\circ} \mathrm{C}$ temperature was the most ideal condition to produce optimum reproducibility in the composting process.

In the early mesophilic phase, mesophilic and fungal bacterial populations number $10^{8}$ and $10^{6}$ for each $1 \mathrm{~g}$ of wet compost. Meanwhile, the thermophilic and actinomycet bacterial population is $10^{4}$ and the thermophilic fungi population is $10^{3}$ for every $1 \mathrm{~g}$ of wet compost. A summary of the bacterial, fungal and actinomycet populations at every composting phase is shown in Table 2.

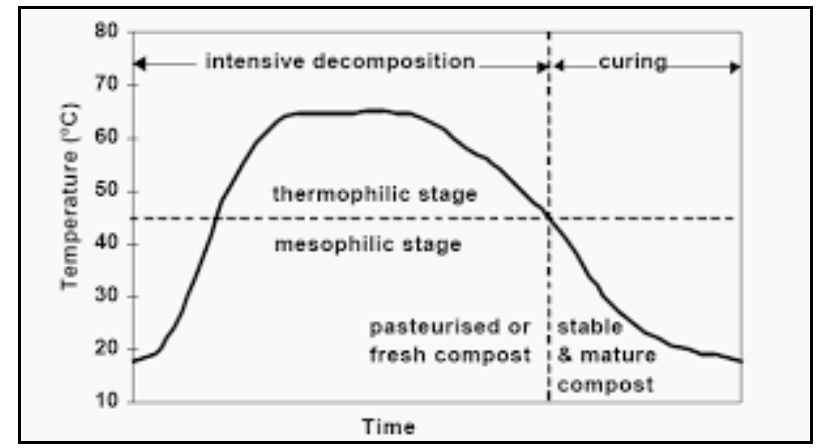

Figure 1. Temperature profile and growth of microorganisms in compost heap

Table 2. Comparison between pile composting and mechanical methods. (Source: Abu Zahrim, 2004)

\begin{tabular}{c|c|c|c}
\hline Microbe & $\begin{array}{c}\text { Mesophilic } \\
\text { Early stage }<\mathbf{4 0}{ }^{\circ} \mathbf{C}\end{array}$ & $\begin{array}{c}\text { Thermophilic } \\
\mathbf{4 0 -} \mathbf{- 6 0} \mathbf{~}^{\circ} \mathbf{C}\end{array}$ & $\begin{array}{c}\text { Thermophilic to } \\
\text { maturation phase }\end{array}$ \\
\hline Bacteria & $10^{8}$ & & $10^{11}$ \\
Mesophilic & $10^{4}$ & $10^{6}$ & $10^{7}$ \\
Thermophilic & $10^{9}$ & & $10^{5}$ \\
\hline Actinomycete & & $10^{8}$ & $10^{5}$ \\
Thermophilic & $10^{6}$ & $10^{3}$ & $10^{6}$ \\
\hline Fungi & $10^{3}$ & $10^{7}$ & \\
Mesophilic & &
\end{tabular}

The increase in temperature is significant for the activity and growth of mesophilic organisms during the initial phase of composting such as lactic acid bacteria, Gramnegative bacteria, yeast, and fungi (Steger et al., 2005). At the thermophilic stage of the composting process, thermophilic organisms dominate the degradation process. The bacterial species that dominate the thermophilic phase of the composting process belong to the genus Bacillus spp. and Thermus thermophiles (Steger et al., 2005). Siu-Rodas et al. (2018), in their study, found that three out of twenty isolated strains showed higher enzymatic activity and were identified as Bacillus subtilis; the study composted coffee residue at a pile temperature of $57^{\circ} \mathrm{C}$. They also discovered that the isolation of 
microorganisms from composting piles in the thermophilic stage allowed for the identification of three $B$. subtilis strains, where the enzymatic extracts showed activity on CMC and crystal cellulose, confirming the existence of endo- and exocellulases. These cellulases could be used in several industries, such as in the preparation of animal foods, fruit juice extraction, and clarification and bleaching of recycled paper. The differences in microbial community were observed clearly at different composting temperatures. The genus Bacillus was dominant at $50{ }^{\circ} \mathrm{C}$ to $70{ }^{\circ} \mathrm{C}$, while the genus Geobacillus increased with the escalation of temperature and dominated at $70{ }^{\circ} \mathrm{C}$ (Bhatia et al., 2013; Ivanov et al., 2001). All these bacteria genera play an important role in the degradation of complex substrates.

The mode of composting and the control levels have a great impact on composting temperature. The highest degree of temperature control is usually obtained in mechanical systems. Large-scale reactors (10-300 1) often comprise a self-heating phase (Lashermes et al., 2012). Previously, Petiot and de Guardia (2004) reported smallvolume reactors resulting in a rapid decrease of temperature due to the reactors' limited amounts of organic substrates and heat losses. Meanwhile, the temperature inside the full-scale reactor declined slowly and gradually. However, temperature, regardless of the method used, is rarely uniform for the entire mass of composting material. The center point of the mass of compost material tends to be warmer than the mass of the composting material on the cooler outer edge. Ali et al. (2014) revealed that the temperature at the inlet zone, middle zone, and outlet zone of the drum varied between $50{ }^{\circ} \mathrm{C}$ to $60{ }^{\circ} \mathrm{C}, 50{ }^{\circ} \mathrm{C}$ to $54{ }^{\circ} \mathrm{C}$, and $30-28{ }^{\circ} \mathrm{C}$ (ambient temperature or slightly higher, signifying the end of the active thermophilic phase), respectively. The variation in temperature range in the three zones inside the reactor is attributed to the microbial activity and accessibility of degradable substances.

Some methods for heating up the pile have been extensively studied to confirm the standard operations for composting. Normally there are 2 methods to heating up the pile. Artificial heating is one of the methods to increase the composting temperature; however, it incurs high cost and energy consumption (Xie et al., 2017). Besides, recent studies have revealed that inoculating microorganisms (bacteria and fungi) in the composting would be beneficial for the composting to pass the start-up period and achieve thermophilic stage even under cold-climate temperature (Gou et al., 2017; Sarkar et al., 2010; Awasthi et al., 2014; Awasthi, 2017).

Elango et al. (2009) investigated the optimal value for reducing the municipal solid waste (MSW) composting time in a thermophilic bioreactor in aerobic conditions. In their study, the thermophilic temperature reached $65-70{ }^{\circ} \mathrm{C}$ within 14 to 21 days of the composting process. After 21 days, the temperature declined gradually, reaching $40{ }^{\circ} \mathrm{C}$ at day 40. They conclude that the use of a thermophilic bioreactor enabled the stabilization of the final compost and led to the production of good humus. At the same time, they also mentioned that the higher the temperature, the longer the retention time in the bioreactor and, in turn, the higher reduction in $\mathrm{C} / \mathrm{N}$ and volatile solids.

Bai and Wang (2011) studied the biodegradation of organic matter (OM) during the aerobic thermophilic phase of human faecal matter. They used a closed reactor system and a thermo-controlled water heater to control the temperature. Under the controlled thermophilic temperature of $60{ }^{\circ} \mathrm{C}$ and with moisture maintained at $60 \%$, more than $70 \%$ of faecal organic matter was obtained in the two-week composting process. They also observed that under thermophilic conditions, ammonification and nitrifications were reduced because of a lack of ammonifying and nitrification bacterial activity. On 
the other hand, thermophilic composting led to more organic nitrogen content being retained without loss of phosphorus (P) in the compost products. Thermophilic composting treatment could also affect the abundance of tetracycline resistance genes (TRGs) especially in the composting of animal manure (including human manures). Kang et al. (2017) reported that short thermophilic composting treatment is insufficient to remove TRGs in the pig manure composting process. The devoting of inactivation of TRGs contain in the animal manure is crucial, because it will be a major source of antibiotic pollution in the soil if the animal manure did not undergo proper thermophilic composting process prior to used directly to the soil.

Besides that, increase in thermophilic temperature in the composting process will help exploit $\mathrm{NH}^{3+}$ gas recovery and would allow the production of a nitrogen source that is free from pathogens and heavy metals (Koyama et al., 2018). During the thermophilic stage, aerobic microorganisms degrade the organic nitrogen of the fresh material into dissolved nitrogen, which, in turn, degrades to $\mathrm{NH}_{4}{ }^{+}-\mathrm{N}$; some element of $\mathrm{NH}_{4}{ }^{+}-\mathrm{N}$ then vaporizes as $\mathrm{NH}^{3+}$ gas. Pagans et al. (2006) also confirmed that $\mathrm{NH}^{3+}$ emission increased at a higher temperature. Various environmental conditions, including temperature, strongly impact the microbial community and cause additional differences in nitrogen dynamics (Wang et al., 2017). Koyama et al. (2018) mentioned in their study that ammonia recaptured from aquacultural sludge could potentially be used for the cultivation of high-value microalgae and the commercial production of medicines, cosmetics, or health supplements. Therefore, in any composting system, the main principle that researchers apply is to develop a composting system that is able to achieve the thermophilic phase. This is because the thermophiles isolated from the high temperature during composting can be further used to develop an inoculum that accelerates the degradation process (Sarkar et al., 2016).

\section{Technical factors affecting thermophilic temperature increase in composting process}

A controlled composting process is crucial to achieving a short processing time at lower costs, and to obtain products that are free of pathogens and odors (Bertoldi et al., 1983). Decomposition is a slow process and offers very slight control of the process conditions such as moisture, temperature, and air supply (Schulze, 1961). Temperature is an important factor in the composting process and depends on the activity of the microbes. Besides that, other parameters that affect the composting process is moisture and oxygen level. Hence, it is essential to identify factors that can significantly increase thermophilic temperature. The subtopics below discuss how rotation/turning frequency, feeding ratio, initial moisture content and aeration rate affect the temperature of the composting process.

\section{Rotation/turning frequency}

Rotation/turning frequency of compost mass is one of the factors affecting the composting rate and quality of compost produced (Tiquia et al., 1997). Rotation or turning for composting can also be performed in a closed reactor system. The main function of rotation in this type of system is to expose compost materials to fresh air, increase oxygen levels, and release heat and gas once the compost products are decomposed (Rynk Richard, 2001). Rotation in a closed system can also reduce air pollution and facilitate the mixing process of the compost pile (Tiquia and Tam, 1998). 
There are many advantages for adapting optimum rotation frequency for the closed reactor system. The main advantages of rotation operation for closed reactor system are to provide ventilation, reduce particle size, ensure that composting materials have the highest temperature, renew microbial activity, and provide fresh material for microbial colonization, so that the ammonia accumulated in the internal void space of the compost is released; thus yielding more uniform compost quality (Diaz et al., 2002; Hackett et al., 1999; Thambirajah and Kuthubutheen, 1989; Biddlestone and Gray, 1991; Parkinson et al., 2004). The rotation process also may increase the functional free air space in the compost (El Kader et al., 2007). Increased free air space can directly increase air renewal or the area of the gas/liquid interface. In addition, increasing free air space increases both oxygen diffusion and the insulation coefficient. This leads to heat production and temperature increase in the compost pile inside the reactor.

Rotation is a preliminary mechanism for controlling ventilation and temperature in composting systems (Tiquia et al., 1997). It is an essential variable in composting and provides both homogenization and aeration to the waste mixture. Furthermore, it controls the composting mixture temperature, the kinetics of the process, and the endproduct sanitation (Smith et al., 2006). Normally, the compost piled through a turning process may experience a reduction in volume by $55 \%$ to $72 \%$ (Larney et al., 2000). This reduction is found in the form of mass elements such as $\mathrm{C}, \mathrm{K}$, and $\mathrm{Na}$ in the compost (Tiquia et al., 2002). Agamuthu (2001) suggests that the turning process should be carried out regularly to ensure that the mass of the compost material contains a moisture content of more than $70 \%$.

However, the disadvantage of high frequency of the rotation process is it may affect the temperature of the compost pile. Therefore, the rotation process must be controlled to ensure that high temperatures are maintained in the compost pile inside the system. Ahmad (2001) states that an excessive rotation process could cause the compost mass to turn cold and dry up, which will indirectly destroy fungi and actinomycetes. Parkinson et al. (2004) also suggest that too much rotation in the composting process would result in the loss of nitrogen in the form of ammonia gas to the atmosphere. This may affect the quality of the compost products, as it may lack important nutrients such as nitrates that are useful for plants. Wan Razali et al. (2012) also mentioned, the fluctuation of temperature in the composting process especially in vessel composting cannot be avoided because of the sludge addition and mechanical turning effect.

Kalamdhad and Kazmi (2009) studied the impact of the rotation process in rotary drum reactors on the quality and stability of the resulting compost product. In their study, the organic waste used was a mixture of cattle stools, wooden ashes, and rotten green vegetables. They found that there was a close correlation between the quality of the compost produced with the frequency of rotation in terms of the value of nitrogen and phosphorus.

Fewer turning frequency would not yield rapid composting, but might be satisfactory for avoiding anaerobic conditions, odors, and maintaining high temperature. A higher turning frequency causes lower temperature and higher moisture loss. In study conducted by Smars et al. (2001), the rotation was limited to only 10-20 min per day. Rodriguez et al. (2012) suggested 12 rotations per hour as necessary for reaching optimal conditions to ensure that the composting would reach high thermophilic temperatures of up to $70{ }^{\circ} \mathrm{C}$. They also argued that a combination of several optimal variables and appropriate reactor designs was essential to ensure that the composting process rapidly achieved thermophilic temperatures and obtained quality final products. 
Table 3 shows the variation of turning frequency for rotary reactor by different references.

Table 3. Variation of rotation frequency for closed reactor

\begin{tabular}{c|c|c}
\hline Variation of rotation frequency & Reactor & Reference \\
\hline 4 rotations/h every $15 \mathrm{~min}$ & Hermetic rotary drum & Scoton et al. (2016) \\
12 rotations/h and 48 rotations/h & Rotary drum & Vodriguez et al. (2012) \\
1 rotation/day for 2 weeks & Rotary drum & Bhatia et al. (2013) \\
1 rotation/day & Full scale rotary drum composter & Kalamdhad and Kazmi (2009) \\
3 rotations every $6 \mathrm{~h} / 12 \mathrm{~h} / 18 \mathrm{~h} / 24 \mathrm{~h}$ & Rotary drum composter & Fernandez et al. (2010) \\
1 rotation/day for 2 weeks and 1 or 2 rotations/week & Pilot scale closed rotary drum & Ali et al. (2014) \\
2 rotations/day & Full scale continuous rotary drum & Sharma et al. (2018) \\
4 rotations/day & Rotary drum composter &
\end{tabular}

\section{Aeration rate}

Oxygen is important for promoting microbial activity in the compost because composting is an aerobic process (involves the presence of oxygen). Therefore, aeration is required for the production of metabolic heat from aerobic microbes. There are three main principles of aeration that can supply oxygen $\left(\mathrm{O}_{2}\right)$ during the process of composting: natural aeration, passive aeration, and active aeration (Epstein, 1997). Aeration, moisture content, and temperature are major factors that affect the composting process because these parameters are interdependent (Talib et al., 2014). A lack of oxygen will result in anaerobic conditions to occur in the compost pile (Polsprasert, 1986). Failure in adjusting for a good aeration system will cause a slow decomposition of organic matter, unpleasant odors, delayed maximum temperature, a low maximum temperature, and slow water removal rate (Diaz et al., 2002; Ferrer et al., 2001; Haug, 1993). Besides, excessive aeration may increase costs and slow down the composting process through heat, water, and ammonia losses. Based on a study conducted by Guo et al. (2012), the aeration rate is a major factor influencing the stability of the compost.

Natural aeration occurs when there is diffusion and natural movement of air in the compost pile. This type of aeration is cheap, easy, and does not require special equipment. Active aeration involves the construction of porous pipes under the compost pile to promote the spread of oxygen gas into the compost waste materials. Meanwhile, passive aeration is highly reliant on the porosity of the matrix pipe because this method uses natural absorption and movement of air inside the pipeline to facilitate the spreading of air into the compost pile. However, using an air ventilation system in the composting process could interfere with temperature stabilization in the compost pile (Barrington et al., 2003). Compared to active aeration, passive aeration modes produce better composting rates. This is because the passive aeration process does not produce a cooling effect on the stack of compost material and can reduce the effect of nitrogen loss to the environment (Habsah, 2008). The lower the aeration rate, the longer the thermophilic temperature stage can be maintained in the composting process (Zang et al., 2016). Otherwise, Alkoaik et al. (2018) in their study mentioned that for the continually rotating drum natural aeriation is suggested by making holes of appropriate size on the drum surface. This is because, the pressure difference between inside and outside the rotating drum will induced aeriation. 
Kasinski et al. (2016) also stated that the application of passive aeration at a larger scale simultaneously permits the thermophilic temperature to be maintained during municipal solid waste composting process and constrains microbial activity in the reactor. Passive aeration permits thermophilic temperature levels in larger-scale composting processes to be retained, which, in turn, allows that biodegradation has occurred and microbial activity has not been repressed. Guo et al. (2012) conducted a statistical analysis on the effect of aeration rate, moisture content, and $\mathrm{C} / \mathrm{N}$ ratio on the stability and maturity of compost pig feces and corn stalk. Their results showed that the aeration rate had a significant influence on the change in temperature $(p=0.023)$. Meanwhile, Talib et al. (2014) found that excessive aeration rate would increase energy conversion, thereby reducing temperature and moisture content. Charles et al. (2009) studied the effect of pre-aeration to start up batch thermophilic anaerobic digestion. They found that a pre-aeration of $48 \mathrm{~h}$ generated sufficient biological heat to increase the temperature of bulk municipal solid waste to $60{ }^{\circ} \mathrm{C}$. Ambient temperature and aeration rate also affected the composting process. Han et al. (2018) investigated the effect of ambient temperature and aeration on thermophilic aerobic composting and found that although the ambient temperature increased in the summer, the upgraded aeration frequency during that season might have accelerated heat loss. They conclude that ambient temperature and aeration frequency influenced the average and highest temperatures of the composting materials. On the other hand, different composting materials and the type of composting system used in different works of literature provide a wide range of aeration rates (Mason, 2007). Table 4 shows the optimum aeration rate for different organic waste composting and raw materials.

Table 4. Optimal aeration rates and thermophilic temperature

\begin{tabular}{|c|c|c|c|}
\hline Optimum aeration rate & Type of waste & $\begin{array}{l}\text { Range of } \\
\text { thermophilic } \\
\text { temperature }\end{array}$ & Reference \\
\hline $0.4 \mathrm{~L} \mathrm{~min}^{-1} \mathrm{~kg}^{-1} \mathrm{OM}$ & $\begin{array}{l}\text { Extraction of tomatoes, peppers, } \\
\text { grass, and eggplant }\end{array}$ & $62-65^{\circ} \mathrm{C}$ & $\begin{array}{c}\text { Kulcu and Yaldiz } \\
\text { (2004) }\end{array}$ \\
\hline $0.25 \mathrm{~L} \mathrm{~min}^{-1} \mathrm{~kg}^{-1} \mathrm{VS}$ & Dairy manure and rice straw & & Luo et al. (2008) \\
\hline $\begin{array}{l}0.6 \mathrm{~L} \mathrm{~min}^{-1} \mathrm{~kg}^{-1} \text { for the active } \\
\text { phase and } 0.4 \mathrm{~L} \mathrm{~min}^{-1} \mathrm{~kg}^{-1} \text { in } \\
\text { the maturation phase }\end{array}$ & Municipal solid waste & $70-73{ }^{\circ} \mathrm{C}$ & $\begin{array}{l}\text { Rasapoor et al. } \\
\qquad(2009)\end{array}$ \\
\hline $\begin{array}{c}0.24,0.48,0.72 \mathrm{~L} \mathrm{~kg}^{-1} \text { dry } \\
\text { matter }(\mathrm{DM}) \mathrm{min}^{-1}\end{array}$ & Pig feces and corn stalk & $>50{ }^{\circ} \mathrm{C}$ & Guo et al. (2012) \\
\hline $0.1 \mathrm{Lmin}^{-1} \mathrm{~m}^{-3}$ & Chicken manure, paddy stalk, grass & $73-74^{\circ} \mathrm{C}$ & Shen et al. (2011) \\
\hline $0.26 \mathrm{Lmin}^{-1} \mathrm{~kg}^{-1} \mathrm{OM}$ & EFB rabbit manure & $70^{\circ} \mathrm{C}$ & Talib et al. (2014) \\
\hline $\begin{array}{c}33.5 \mathrm{~L} / \mathrm{h} / \mathrm{kg} \text { of initial waste } \\
\text { mass }\end{array}$ & Municipal waste & $70-73{ }^{\circ} \mathrm{C}$ & $\begin{array}{l}\text { Kasinski et al. } \\
\quad(2016)\end{array}$ \\
\hline $42-48 \mathrm{~m}^{3} \mathrm{~min}^{-1}$ & Municipal sewage sludge & $53-80{ }^{\circ} \mathrm{C}$ & Han et al. (2018) \\
\hline
\end{tabular}

\section{Initial moisture content}

Moisture content in the composting process can affect microbial activity and, in turn, affect the temperature and decomposition rate of composting materials. Moisture content can also affect the composition of the microbial population (Coppola et al., 
1983). The optimum moisture content in the composting process is between $50 \%$ and 60\% (Liang et al., 2003; Eipstein, 1997; Tiquia et al., 1997; Schulze, 1961; Poincelot, 1975). For moisture content that is below $40 \%$, microbial activity can be reduced, but if moisture content exceeds $60 \%$, anaerobic conditions may occur due to a wedged pore space. Excessive moisture will result in the problem of nutrient loss and pathogens leaking out in leachate form. This condition may also interfere with airflow and temperature in the compost pile. According to Metcalf and Eddy (2003), the optimum moisture content of a non-reactor system (pile method) is $60 \%$ and $65 \%$ for a reactor system (mechanical method).

The change in moisture content in composting varies depending on the composting method, the bulking agent, and the raw materials used (Day and Shaw, 2001). The initial moisture level of past experiments varied and was dependent on the concentration of the compost mixture and material (Villasenor et al., 2011). According to Liang et al. (2003), the moisture content process, as well as the temperature to increase microbial activity, should be given more priority in the composting process. Another study agreed, mentioning that optimum moisture content would accelerate the flow of oxygen, which, in turn, increases the activity of microbes, accelerates decomposition, and increases the thermophilic temperature and reduce odor (Goldstein, 2002; Liang et al., 2003; Schaub and Leonard, 1996).

Luo et al. (2008) found that increasing the volumetric mixing ratios of the bulking agent for sewage sludge in the upper half zone of the compost pile could increase the temperature increment rate, achieve uniform temperature distribution, prolong the thermophilic temperature stage, and kill most pathogenic organisms in different layers of the pile, given that the initial moisture content of the mixture was adjusted to about $60 \%$. They also suggested that high initial moisture content in the compost mixture for co-composting gave very low composting effectiveness because of an absence of the thermophilic stage in both the top and middle layers of the pile. Otherwise, excessive moisture will inhibit airflow in the system and will not allow the temperature to increase (Sarkar et al., 2016).

Tiquia et al. (1996) found that different moisture levels in the compost pile gave a different effect on temperature. At 50\% and 60\% initial moisture levels, the highest temperature achieved was around $64-69{ }^{\circ} \mathrm{C}$. Meanwhile, at $70 \%$ moisture content, the pile would cool early and the production of microbial activity and biomass decrease, whereas the highest temperature achieved was $58^{\circ} \mathrm{C}$. Zang et al. (2016), in their study, observed a relationship between initial moisture content and thermophilic temperature for which moisture content significantly influenced composting temperature $(\mathrm{p}<0.001)$. High initial moisture content may cause limited oxygen transfer and diffusion and increased heat capacity of the compost. On the other hand, composting temperature can also be affected by feedstock mix ratio, as feedstock ratio may relate to the initial moisture content. However, Petric et al. (2009) demonstrated that for composting of poultry manure and wheat straw, relatively high initial moisture content was better for achieving higher temperatures and retaining them for longer times. A wide range of optimum moisture content indicates: i) the complex dynamic nature of the composting process, with changes in particle size and structure occurring over time, and ii) the necessity for more fundamental and inclusive parameters to understand the physical and biological interactions controlling the composting process (Zavala and Funamizu, 2005). Table 5 shows the different initial moisture content (\%) for different type of waste. 
High moisture content can also lead to increased losses of ammonia, which must be controlled with the addition of suitable additives. The findings of Petric et al. (2009) suggest that initial moisture content of around $69 \%$ can be considered as suitable for the efficient composting of poultry manure mixed with wheat straw. Otherwise, Sarkar et al. (2016) mentioned that composting would be at its most efficient if the important thermophilic phase was reached and only if the moisture content was kept around $60 \%$. Ali et al. (2014) determined that the reduction of moisture content in the inlet, middle, and outlet zones during composting in a rotary drum reactor caused a higher degree of temperature and evaporation losses to the surrounding air. The moisture content tended to decrease due to the combination of high-temperature levels and aeration during the thermophilic temperature phase (Lashermes et al., 2012; Villasenor et al., 2011). Hence, in order to control the optimum moisture content in the composting process, the continuous monitoring of the moisture in the compost mixture must be carried out regularly. Some studies conclude that the moisture content of the compost mixture in a closed reactor and its stabilization at about 50\% $( \pm 2 \%)$ could lead to increased stabilization of temperature at the thermophilic level (Kasinski et al., 2016; Liang et al., 2003).

Table 5. Initial moisture content for different type of waste

\begin{tabular}{c|c|c}
\hline $\begin{array}{c}\text { Initial moisture } \\
\text { content }(\%)\end{array}$ & Type of waste & Reference \\
\hline$<64$ & Bio toilet & Zavala and Funamizu (2005) \\
60 & Pig manure and corn stalks & Zang et al. (2016) \\
$>60$ & Municipal solid waste & Elango et al. (2009) \\
75 & Vegetable waste & Ali et al. (2014) \\
66 & Sewage sludge, branches, grass dipping and leaves & Lashermes et al. (2012) \\
$70-75$ & Cattle manure and rice straw & Hoseini and Aziz (2013) \\
\pm 67 & Chicken manure and carnation waste & Kulcu et al. (2008) \\
60 & Sawdust and human feces & Bai and Wang (2011) \\
60 & Green waste, sugar beet pulp and paper waste & Zhang and Sun (2018) \\
$75-82$ & Flower waste, cow dung & Sharma et al. (2018) \\
\hline
\end{tabular}

\section{Conclusion}

Optimizing the process of composting is an important step in obtaining an effective process and good compost quality. The commonly used method of composting in plantations is the pile method. Normally, the pile method, along with the periodic turning process, is adopted. As mentioned in many studies, composting using this method invites many problems, especially the composting period process, which is too long (usually taking more than 80 days for the entire process), the presence of wild animals such as snakes, and also its requirement for more sophisticated operational controls along with its large space and also the concern of GHG gas emission that can lead to the increasing of greenhouse gas emission to the atmosphere. Therefore, composting using mechanical methods in a closed reactor is easier and is able to overcome the problems resulting from composting using the pile method. However, in a closed-reactor composting process, inadequate stabilization of the compost normally occurs due to its short residence time in a biologically active system (Singh et al., 2009; 
Kalamdhad et al., 2008). Due to the absence of extensive reviews of thermophilic temperature rise in closed reactors, this paper presents the basic knowledge to a new researcher in composting studies to obtain optimum composting process quality. For closed reactors, aeration rate, rotation frequency and initial moisture content of compost materials play an important role in the effort to achieve optimum temperature of composting. On the other hand, Rich and Bharti (2015) also mentioned that, the material used of the closed reactor manufacturing which is metal, and a good conductor is also as essential to retain the temperature of compost material in the reactor.

Although the composting method via closed reactors has proven to be technically effective, there are many other aspects of the operation that need to be improved, so that existing system facilities can implement the method more efficiently. One of the most important aspects of using rotary drum reactors is its air diversion system, which stimulates the decomposition of microbes in organic waste. The exothermic process plays an important role in increasing the composting temperature from ambient to thermophilic temperature. For a closed reactor, rotation is one of the methods to supply air to organic waste. An optimum rotation process is important to expose fresh organic waste to the microbial population and thus freeing the accumulated ammonia in the air composite material, while at the same time maintaining the temperature of the compost heap in the reactor.

Vigilant control of the composting process at the microbial level comprises four interrelated factors: metabolic heat generation, temperature, aeration, and moisture content. A critical element of control is the maintenance of temperature within a required range since temperature both imitates prior microbial activity and strongly regulates the current rate of activity. This key relationship has previously been proven via the assessment of the response of this ecosystem to temperature using physical and chemical measurements. From the reviewed literature, it can be concluded that a fewer rotation/turning frequency allows the high temperature in the compost material inside the reactor to be maintained. Passive aeration is a more favorable condition for supplying air in the closed reactor and to retain the thermophilic temperature in the compost pile. Finally, the moisture content must be kept around $\pm 60 \%$ to increase microbial activity without inhibiting the thermophilic-stage temperature.

\section{REFERENCES}

[1] Abu Zahrim, Y. (2004): Pengkomposan enapcemar perawatan ais sisa industri. - M. Eng Thesis. Universiti Kebangsaan Malaysia.

[2] Agamuthu, P. (2001): Solid Waste: Principle and Management with Malaysian Case Studies. - University of Malaya Press, Kuala Lumpur.

[3] Ahmad, J. (2001): Proses pengkomposan bahan-bahan organik dari aliran sisa pejal domestic dengan menggunakan reaktor aerobic. - Tesis Msc. Universiti Sains Malaysia.

[4] Ali, M., Kazmi, A. A., Ahmed, N. (2014): Study on effects of temperature, moisture and $\mathrm{pH}$ in degradation and degradation kinetics of aldrin, endosulfan, lindane pesticides during full-scale continuous rotary drum composting. - Chemosphere 102: 68-75.

[5] Alkoaik, F. N., Abdel-Ghany, A. M., Rashwan, M. A., Fulleros, R. B., Ibrahim, M. N. (2018): Energy analysis of a rotary drum bioreactor for composting tomato plant residues. - Energies 11(449): 2-14.

[6] Awasthi, M. K., Pandey, A. K., Khan, J., Bundela, P. S., Wong, J. W. C., Selvam, A. (2014): Evaluation of thermophilic fungal consortium for organic municipal solid waste composting. - Bioresource Technology 168: 214-221. 
[7] Awasthi, M. K., Selvam, A., Lai, K. M., Wong, J. W. C. (2017): Critical evaluation of post-consumption food waste composting employing thermophilic bacterial consortium. Bioresour. Technol. 245: 665-672.

[8] Bai, F., Wang, X. (2011): Biodegradation of Organic matter and holding of N, P during aerobic thermophilic composting of human feces. - Procedia Environmental Sciences 10: 2631-2637.

[9] Barrington, S., Choiniere, D., Trigui, M., Knight, W. (2003): Compost convective airflow under passive aeration. - Bioresource Technology 86: 259-266.

[10] Bernal, M. P., Paredes, C., Sanchez-Monedero, M. A., Roig, A. (1998): Carbon mineralization from organik waste at different composting stages during their incubation with soil. - Agr. Ecosyst. Environ. 69: 175-189.

[11] Bernal, M. P., Alburquerque, J. A., Moral, R. (2009): Composting of animal manures and chemical criteria for compost maturity assessment. A review. - Bioresour. Technol. 100: 5444-5453.

[12] Bertoldi, M., Vallini, G., Pera, A. (1983): The biology of composting: a review. - Waste Management Res. 1(2): 157-176.

[13] Bhamidimarri, S. M. R. Pandey, S. P. (1996): Aerobic thermophilic composting of piggery solid wastes. - Water Science \& Technology 33(8): 89-94.

[14] Bhatia, A., Madan, S., Sahoo, J., Ali, M., Pathania, R., Kazmi, A. A. (2013): Diversity of bacterial isolates during full scale rotary drum composting. - Waste Management 33: 1595-1601.

[15] Bhattarai, R., Kalita, P. K., Yatsu, S., Howard, H. R., Svendsen, N. G. (2011): Evaluation of compost blankets for erosion control from disturbed lands. - Journal of Environmental Management 92: 803-812.

[16] Biddlestone, A. J. Gray, K. R. (1988): A Review of Aerobic Biodegradation of Solid Waste. - In: Houghton, D. R., Smith, R. N. Eggins, H. O. W. (eds.) Biodeteriotion 7. Elsevier Science Publisher Ltd, Amsterdam, pp 825-839.

[17] Charles, W., L. Walker, L., Cord-Ruwisch, R. (2009): Effect of pre-aeration and inoculum on the start-up of batch thermophilic anaerobic digestion of municipal solid waste. - Bioresource Technology 100: 2329-2335.

[18] Chen, R., Wang, Y., Wang, W., Wei, S., Jing, Z., Lin, X. (2015): $\mathrm{N}_{2} \mathrm{O}$ emissions and nitrogen transformation during windrow composting of dairy manure. - Journal of Environmental Management 160: 121-127.

[19] Coppola, S., Dumontet, S. Marino, P. (1983): Composting Raw Sewage Sludge in Mixture with Organic or Inert Bulking Agents. - In: Stentiford, E. I. (ed.) Proceeding of the International Conference on Composting of Solid Waste and Slurries. The University of Leeds, England, pp 125-147.

[20] Day, M. Shaw, K. (2001): Biological, Chemical and Physical Processes of Composting. In: Stofella, P. J., Kahn, B. A. (eds.) Compost Utilization in Horticulture Cropping Systems. : Lewis Publisher, USA.

[21] Diaz, M. J., Madejon, E., Lopez, R. Cabrera, F. (2002): Composting of vinasse and cotton gin wastes by using two different systems. - Resource, Conservations and Recycling 34: 235-248.

[22] Epstein, E. (1997): The Science of Composting. - Technomic Publishing Company, Inc, USA.

[23] Elango, D., Thinakaran, N., Panneerselvam, P., Sivanesan, S. (2009): Thermophilic composting of municipal solid waste. - Applied Energy 86: 663-668.

[24] El Kader, N. A., Robin, P., Paillat, J. M., Leterme, P. (2007): Turning, compacting and the addition of water as factors affecting gaseous emissions in farm manure composting. - Bioresource Technology 98: 2619-2628.

[25] Fernandez, F. J., Sanchez-Arias, V., Rodriguez, L., Villasenor, J. (2010): Feasibility of composting combinations of sewage sludge, olive mill waste and winery waste in a rotary drum reactor. - Waste Management 30: 1948-1956. 
[26] Ferrer, J., Paez, G., Marmol, Z., Ramones, E., Chandler, C., Marin, M., Ferrer, A. (2001): Agronomic use of biotechnologically processed grape wastes. - Bioresource Technology 76(1): 39-44.

[27] Gea, T., Artolla, A., Sanchez, A. (2005): Composting of de-inking sludge from the recycled paper manufacturing industry. - Bioresource Technology 96(10): 1161-1167.

[28] Goldstein, N. (2002): Quick to implement odour reduction techniques. - Bio Cycle 1: 29.

[29] Gou, C., Wang, Y., Zhang, X., Lou, Y., Gao, Y. (2017): Inoculation with a psychrotrophic-thermophilic complex microbial agent accelerates onset and promotes maturity of dairy manure-rice straw composting under cold climate conditions. Bioresource Technology 243: 339-346.

[30] Guo, M., Liang, F., Yu, A. Yang, L. (2012): Evaluation of stability and maturity during forced-aeration composting of chicken manure and sawdust at different $\mathrm{C} / \mathrm{N}$ ratios. Chemosphere 78: 614-619.

[31] Habsah, N. M. S. (2008): Pengkomposan sisa taman menggunakan kaedah timbunan statik berudara dan drum berputar. - Tesis M.Eng, Universiti Sains Malaysia, Pulau Pinang, pp. 1-227.

[32] Hackett, G. A. R., Easton, C. A. Duff, S. J. B. (1999): Composting of pulp and paper mill fly ash with wastewater treatment sludge. - Bioresource Technology 70: 217-224.

[33] Han, Z., Sun, D., Wang, H., Li, R., Bao, Z., Qi, F. (2018): Effects of ambient temperature and aeration frequency on emissions of ammonia and greenhouse gases from a sewage sludge aerobic composting plant. - Bioresource Technology 270: 457-466.

[34] Haug, R. T. (1993): The Practical Handbook of Compost Engineering. - McGraw-Hill International Editions, New York.

[35] He, X. S., Xi, B. D., Cui, D. Y., Liu, Y., Tan, W. B., Pan, H. W., Li, D. (2014): Influence of chemical and structural evolution of dissolved organic matter on electron transfer capacity during composting. - Journal of Hazardous Material 268(15): 256-263.

[36] Hiroaki, T., Kodaira, S., Kimoto, A., Nashimoto, M. Takagi, M. (2006): Microbial communities in the garbage composting with rice hull as an amendment revealed by culture dependent and independent approaches. - Journal Bioscience Bioengineering 101(1): 42-50.

[37] Hosseini, S. M., Abdul Aziz, H. (2013): Evaluation of thermochemical pretreatment and continuous thermophilic condition in rice straw composting process enhancement. Bioresource Technology 133: 240-247.

[38] Ivanov, M. V., Lysenko, A. M., Petrunyaka, V. V., Ivanova, A. E., Nazina, T. N., Poltaraus, A. B., Tourova, T. P., Belyaev, S. S., Grigoryan, A. A., Novikova, E. V., Osipov, G. A. (2001): Taxonomic study of aerobic thermophilic bacilli: descriptions of Geobacillus subterraneus gen. nov., sp. nov. and Geobacillus uzenensis sp. nov. from petroleum reservoirs and transfer of Bacillus stearothermophilus, Bacillus thermocatenulatus, Bacillus thermoleovorans, Bacillus kaustophilus, Bacillus thermodenitrificans to Geobacillus as the new combinations G. stearothermophilus, G. th. - Int. J. Syst. Evol. Microbiol. 51: 433-446.

[39] Kang, Y., Li, Q., Xia, D., Shen, M., Mei, L., Hua, J. (2017): Short-term thermophilic treatment cannot remove tetracyclineresistance genes in pig manures but exhibits controlling effects ontheir accumulation and spread in soil. - Journal of Hazardous Materials 340: 213-220.

[40] Kalamdhad, A. S. Kazmi, A. A. (2009): Effects of turning frequency and compost stability and some chemical characteristics in a rotary drum composter. - Chemosphere 74: $1327-1334$

[41] Kalamdhad, A. S., Pasha, M., Kazmi, A. A. (2008): Stability evaluation of compost by respiration methods in a rotary drum composter. - Res Cons Recy. 52: 829-34.

[42] Kasinski, S., Slota, M., Markowski, M., Kaminska, A. (2016): Municipal waste stabilization in a reactor with an integrated active and passive aeration system. - Waste Management 50: 31-38. 
[43] Koyama, M., Nagao, N., Syukrib, F., Abd Rahim, A., Kamarudin, M. S., Todac, T., Mitsuhashia, T., Nakasakia, K. (2018): Effect of temperature on thermophilic composting of aquaculture sludge: $\mathrm{NH}_{3}$ recovery, nitrogen mass balance, and microbial community dynamics. - Bioresource Technology 265: 207-213.

[44] Kulcu, R., Yaldiz, O. (2004): Effects of air flow directions on composting process temperature profile. - Waste Management 28: 1766-1772.

[45] Kulcu, R., Sonmez, I., Yaldiz, O., Kaplan, M. (2008): Composting of spent mushroom compost, carnation wastes, chicken and cattle manures. - Bioresource Technology 99(17): 8259-8264.

[46] Larney, F. J., Olson, A. F., Carcamo, A. A. Chang, C. (2000): Physical changes during active and passive composting of beef feedlof manure in winter and summer. Bioresource Technology 75: 139-148.

[47] Lashermes, G., Barriuso, E., Le Villio-Poitrenaud, M., Houot, S. (2012): Composting in small laboratory pilots: Performance and reproducibility. - Waste Management 32: 271277.

[48] Liu, J. (2000): Composting and use of compost as a soil amendment. - Ph.D thesis. Department of Astronomy and Soil Science, University of Hawaii.

[49] Li, R., Li, L., Huang, R., Sun, Y., Mei, X., Shen, B., Shen, Q. (2014): Variations of culturable thermophilic microbe numbers. and bacterial communities during the thermophilic phase of composting. - World J Microbiol Biotechnol 30: 1737-1746.

[50] Liang, C., Das, K. C. McClendon, R. W. (2003): The influence of temperature and moisture contents regimes on the aerobic microbial activity of a biosolids composting blend. - Bioresource Technology 86(2): 131-137.

[51] Liang, Y., Leonard, J. J., Feddes, J. J. R., McGill, W. B. (2006): Influence of carbon and buffer amendment on ammonia volatilization in composting. - Bioresource Technology 97(5): 748-761.

[52] Luo, W., Chen, T. B., Zheng, G. D., Gao, D., Zhang, Y. A. Gao, W. (2008): Effect of moisture adjustments on vertical temperature distribution during forced-aeration staticpile composting of sewage sludge. - Resources, Conservation Recycling 52: 635-642.

[53] Mason, I. G. (2007): A study of power, kinetics and modellling in the composting process. - Tesis Ph.D, University of Canterbury, Christchurch, New Zealand: 1-230.

[54] Metcalf Eddy. (2003): Wastewater Engineering Treatment and Reuse. - McGraw-Hill, Inc., New York.

[55] Mohammad, N., Alam, M. Z., Kabbashi, N. A. Ahsan, A. (2012): Effective composting of oil palm industrial waste by filamentous fungi: A review. - Resource, Conservation \& Recycling 58: 69-78.

[56] Morales, A. B., Bustamante, M. A., Marhuenda-Egea, F. C., Moral, R., Ros, M., Pascual, J. A. (2016): Agri-food sludge management using different co-composting strategies: study of the added value of the composts obtained. - J. Clean. Prod. 121: 186-197.

[57] Pagans, E., Barrena, R., Font, X., Sánchez, A. (2006): Ammonia emissions from the composting of different organic wastes. Dependency on process temperature. Chemosphere 62: 1534-1542.

[58] Parkinson, R., Gibbs, P., Burchett, S. Misselbrook, T. (2004): Effect of turning regime and seasonal weather conditions on nitrogen and phosphorus losses during aerobic composting. - Bioresource Technology 916: 171-178.

[59] Petiot, C., de Guardia, A. (2004): Composting in a laboratory reactor: a review. Compost Science \& Utilization 12: 69-79.

[60] Petric, I., Selimbasic, V. (2008): Composting of poultry manure and wheat straw in a closed reactor: optimum mixture ratio and evolution of parameters. - Biodegradation 19: 53-63.

[61] Petric, I., Šestan, A., Šestan, I. (2009): Influence of initial moisture content on the composting of poultry manure with wheat straw. - Biosystem Engineering 104(1): 125134. 
[62] Poincelot, R. P. (1975): The Biochemistry and Methodology of Composting. - Bull. 754. The Connecticut Agr. Expt. Station, New Haven, CT.

[63] Polprasert, C., Edwards, P., Rajput, V. S. C., Pacharaprakiti, C. (1986): Integrated biogas technology in the tropics 1. Performance of small-scale digesters. - Waste Management \& Research 4(2): 197-213.

[64] Rasapoor, M., Nasrabadi, T., Kamali, M. Hoveidi, H. (2009): The effects of aeration rates on generated compost quality, using aerated static pile method. - Waste Management 29: 570-573.

[65] Rashad, F. M., Saleh, W. D., Moselhy, M. A. (2010): Bioconversion of rice straw and certain agro industrial wastes to amendments for organic farming systems: 1 . Composting, quality, stability and maturity indices. - Bioresource Technology 101: 59525960.

[66] Rich, N., Bharti, A. (2015): Assessment of different types of in-vessel composters and its effect on stabilization of MSW compost. - International Research Journal of Engineering and Technology 2(3): 37-42.

[67] Rodriguez, L., Maria, I. C., Valentin, G. A., Villasenor, J. (2012): Domestic sewage sludge composting in a rotary drum reactor: optimizing the thermophilic stage. - Journal of Environmental Management 112: 284-291.

[68] Rynk, R. Richard, T. L. (2001): Commercial Compost Production System. - In: Stofella, P. J., Khan, B. A. (eds.) Compost Utilization in Horticulture Cropping Systems, pp: 3655. Lewis Publisher, USA.

[69] Sarkar, S., Banerjee, R., Chanda, S., Das, P., Ganguly, S., Pal, S. (2010): Effectiveness of inoculation with isolated Geobacillus strains in the thermophilic stage of vegetable waste composting. - Bioresource Technology 101: 2892-2895.

[70] Sarkar, S., Pal, S., Sunanda Chanda, S. (2016): Optimization of a vegetable waste composting process with a significant thermophilic phase. - Procedia Environmental Sciences 35: 435-440.

[71] Schaub, S. M. Leonard, J. J. (1996): Composting: an alternative waste management option for food processing industries. - Trends in Food Science and Technology 7: 263268.

[72] Schulze, K. L. (1961): Continuous thermophilic composting. - Applied Microbiology 10: 108-122.

[73] Scoton, E. J., Battistelle, R. A. G., Bezerra. B. S., Akutsu, J. (2016): A sewage sludge co composting process using respirometric monitoring method in hermetic rotary reactor. Journal of Cleaner Production 121: 169-175.

[74] Sharma, D., Yadav, K. D., Kumar, S. (2018): Role of sawdust and cow dung on compost maturity during rotary drum composting of flower waste. - Bioresource Technology 264: 285-289.

[75] Shen, Y., Ren, L., Li, G., Chen, T., Guo, R. (2011): Influence of aeration on $\mathrm{CH}_{4}, \mathrm{~N}_{2} \mathrm{O}$ and $\mathrm{NH}_{3}$ emissions during aerobic composting of a chicken manure and high $\mathrm{C} / \mathrm{N}$ waste mixture. - Waste Management 31: 33-38.

[76] Singh, Y. T., Kalamdhad, A. S., Ali, M., Kazmi, A. A. (2009): Maturation of primary stabilized compost from rotary drum composter. - Resources, Conservation and Recycling 53: 386-392.

[77] Siu-Rodas, Y., Calixto-Romoa, M. D. L. A., Guillén-Navarro, K., Sánchez, J. E., Zamora-Brise noa, J. A., Lorena Amaya-Delgado, L. (2018): Bacillus subtilis with endocellulase and exocellulase activities isolated in the thermophilic phase from composting with coffee residues. - Rev Argent Microbiol. 50(3): 234-243.

[78] Smars, S., Beck-Friis, B., Jonsson, H. Kirchmann, H. (2001): An advanced experimental composting reactor for systematic simulation studies. - Journal of Agriculture Engineering Research 78(4): 415-422. 
[79] Smith, D. R., Cawton, D. L., Sloan, J. J., Freeman, T. M. (2006): In-vessel mechanical rotating drum composting of institutional food residuals. - Compost. Sci. Util. 14: 155161.

[80] Steger, K., Eklind, Y., Olsson, J., Sundh, I. (2005): Microbial community growth and utilization of carbon constituents during thermophilic composting at different oxygen levels. - Microbial Ecology 50: 163-171.

[81] Stentiford, E. I. (1996): Composting Control: Principle and Practice. - In: de Bertoldi, M., Sequi, P., Lemans, B. P., Papi, T. (eds.). The Science of Composting: Part 1. Blackie Academic and Professional, Blackie, Glasgow.

[82] Sun, Q., Wu, D., Zhang, Z., Zhao, Y., Xie, X., Wu, J., Lu, Q., Wei, Z. (2017): Effect of cold-adapted microbial agent inoculation on enzyme activities during composting start-up at low temperature. - Bioresource Technology 244: 635-640.

[83] Talib, A. T., Mokhtar, M. N., Baharuddin, A. S., Sulaiman, A. (2014): Effect of aeration rate on degradation process of oil palm empty fruit bunch with kinetic-dynamic modelling. - Bioresource Technology 169: 428-438.

[84] Thambirajah, J. J. Kuthubutheen, A. J. (1989): Composting of palm press fibre. Biological Wastes 27: 257-269.

[85] Tiquia, S. M. Tam, N. F. Y. (1998): Composting of spent pig litter in turned and forcedaerated piles. - Environmental Pollution 99: 329-337.

[86] Tiquia, S. M., Tam, N. F. Y. Hodgkis, I. J. (1996): Microbial activities during composting of spent manure sawdust litter at different moisture content. - Bioresource Technology 55: 201-205.

[87] Tiquia, S. M., Tam, N. F. Y. Hodgkis, I. J. (1997): Effects of turning frequency on composting of spent pig-manure sawdust litter. - Bioresource Technology 62(1-2): 37-42.

[88] Tiquia, S. M., Wan, J. H. C., Tam, N. F. Y. (2002): Dynamics of yard trimmings composting as determined by dehydrogenase activity, ATP content, arginine ammonification, and nitrification potential. - Process Biochemistry 37(10): 1057-1065.

[89] Villasenor, J., Rodriguez, I. Fernandez, F. J. (2011): Composting domestic sewage sludge with natural zeolites in a rotary drum reactor. - Bioresource Technology 102: 1447-1454.

[90] Wan Razali, W. A., Baharuddin, A. S., Talib, A. T., Sulaiman, A., Naim, M. N., Hassan, M. A., Shirai, Y. (2012): Degradation of oil palm empty fruit bunches (OPEFB) fibre during composting process using in-vessel composter. - BioResource 7(4): 4786-4805.

[91] Wang, X., Pan, S., Zhang, Z., Lin, X., Zhang, Y., Chen, S. (2017): Effects of the feeding ratio of food waste on fed-batch aerobic composting and its microbial community. Bioresource Technology 224: 397-404.

[92] Wong, J. W. C., Mak, K. F., Chan, N. W., Lam, A., Fang, M., Zhou, L. X., Wu, Q. T., Liao, X. D. (2001): Co-composting of soybean residues and leaves in Hong Kong. Bioresource Technology 76(2): 99-106.

[93] Xie, X. Y., Zhao, Y., Sun, Q. H., Wang, X. Q., Cui, H. Y., Zhang, X., Li, Y. J., Wei, Z. M. (2017): A novel method for contributing to composting start-up at low temperature by inoculating cold-adapted microbial consortium. - Bioresource Technology 238: 39-47.

[94] Yang, F., Li, G. X., Yang, Q. Y., Luo, W. H. (2013). Effect of bulking agents on maturity and gaseous emissions during kitchen waste composting. - Chemosphere 93(7): 13931399.

[95] Zang, B., Li, S., Michel Jr. F., Li, G., Luo, Y., Zhang, D., Li, Y. (2016): Effects of mix ratio, moisture content and aeration rate on sulfur odor emissions during pig manure composting. - Waste Management 56: 498-505.

[96] Zavala, M. A. L., Funamizu, N. (2005): Effect of moisture content on the composting process in a biotoilet system. - Compost Science \& Utilization 13(3): 208-216.

[97] Zhang, L. Sun, X. (2018): Influence of sugar beet pulp and paper waste as bulking agents on physical, chemical, and microbial properties during green waste composting. Bioresource Technology 267: 182-191. 


$$
\text { - } 9996 \text { - }
$$

[98] Zhang, X., Zhao, Y., Zhu, L., Cui, H., Jia, L., Xie, X., Li, J., Wei, Z. (2017): Assessing the use of composts from multiple sources based on the characteristics of carbon mineralization in soil. - Waste Management 70: 30-36.

[99] Zhao, X. Y., He, X. S., Xi, B. D., Gao, R., Tan, W. B., Zhang, H., Li, D. (2016): The evolution of water extractable organic matter and its association with microbial community dynamics during municipal solid waste composting. - Waste Management 56: 79-87.

[100] Zhu-Barker, X., Bailey, S. K., U, K. T. P., Burger, M., Horwath, W. R. (2017): Greenhouse gas emissions from green waste composting windrow. - Waste Management 59: 70-79. 